\title{
ゴムの配合剤の分析(有機系配合剤)
}

\author{
菊 地 貴子*1.大 武 義 人*2
}

\section{The Analysis of Additives in Rubber Products}

Takako KIKUCHI, Yoshito OHTAKE (Chemicals Evaluation and Research Institute, Japan 1600 Shimotakano, Sugitomachi, Kitakatsushika-gun, Saitama, 345-0043, Japan)

Rubber products contain some kinds of additives such as vulcanizing agents, crosslinking agents, vulcanization accelerators, antioxidants, plasticizers, flame retardants and fillers.

In general, when we perform the analysis of rubber products, additives are extracted from rubber products at the first step. Therefore, it is very important to select a extraction method in the preparation, for example the solvent extraction, SFE, the thermal extraction. The extracts that contain various additives is analyzed by Chromatography such as TLC, GC/MS and LC/MS at the second step. We suggest same preparation and chromatographic analysis involving TLC, GC/MS and LC/MS

Key Words : Extraction, Vulcanization Accelerator, Antioxidant, Flame Retardant, TLC, GC/MS

\section{1.は じめ に}

ゴム製品には可塑剤, 老化防止剤, 加硫剤, 加硫促進剤, 難燃郕，加工助郕等々様々な種類の添加剤が混合されてい る。近年ゴム製品に求められる性能はますます高度化して おり，ゴムの配合設計は添加剤の種類はもとより配合比ま たは添加戍の組み合わせなど，より複雑となっている。こ れらの添加剤の分析を正確に行うためには分析技術を熟知 するだけでなく, 添加剤そのものの化学的, 物理的性質を 理解し, 実際に配合される添加剤の種類や量に関する基本 的知識をもつことが必要であろう。

一方でこれら加硫ゴムに添加されている配合剤が同じ装 置に組み込まれている様々な他の材料のトラブルを誘引す る一原因になっている側面もあり, 配合剂の分析を熟知し て扔くことは, 品質管理ばかりでなく材料のトラブル解析 にも大変重要になる ${ }^{1-3)}$.

添加剤の分析は基本的には有機溶媒への溶解性の差異や 熱的性質を利用してゴム製品から添加剂を分画し，得られ
*1 (狽化学物質評価研究機構 ( $7345-0043$ 埼玉 県北葛飾郡杉戸町下高野 1600 番地) 高分子 技術部 技術第二課 副長。平成 6 年, 千 葉大学工学部卒業. 同年(斯)化学物質評価研 究機構入所, 現在に至る. 専門は, 高分子 化学, 高分子分析.
た分画物の分析を行う。また未知試料の添加剂を分析する 場合と既知の添加剂の分析を行う場合とで分析の手順が異 なるため注意が必要である.フィラー等の無機化合物の分 析には, 前処理工程で変化する場合も多々あるため, X線 回折分析等で直接分析することが望ましい，今回はゴム配 合剂の中でも加硫剤, 加硫促進剤, 老化防止剂及び難燃剂 に絞り, 分析手法について述べるとともに, 添加剤に由来 するトラブルについても紙面の許す限り述べてみたい.

\section{2. 前 処 理}

まずゴム製品から添加剤を抽出分離し濃縮を行う．次に 得られた抽出物をクロマトグラフィーによりさらに個々成 分に分離し，それぞれにういて定性または定量を行うのが 一般的である。直接分析する方法もあるが，未知試料の場 合はゴムから添加剤を分離して，その物質の性質に適した 分析を行うことで，より精度が向上する.

\section{1 再沈法}

合成ゴムは合成過程で用いられた乳化剂や凝固剤などを

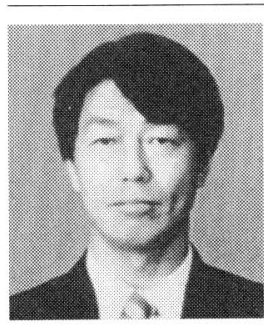

*2 財化学物質評価研究機構 ( 県北葛飾郡杉戸町下高野 1600 番地) 高分子 技術センター所長. 理事.国立小山高専 工 業技術科 昭和 47 年卒業 (工博). 昭和 57 年 (斯)化学品検查協会入会, 専門滈分子化学. 環境劣化研究分科会主査. 
含んでいる．天然ゴム (NR)にはたんぱく質や自然界の老 化防止戍など多種の不純物が含まれている。詳細な分析を 行う場合, 前もってこれら不純物を取り除くことがある. 手法として一般に再沈法がとられる. 再沈法は生ゴムをク ロロホルムまたはトルエンなどの良溶媒に溶かした後，ア ルコールなどの貧溶媒を加えゴム分を沈殿させる操作を繰 り返し，ゴム分とそれ以外の添加剤成分に分離する手法で ある。

再沈法はプラスチックや熱可塑性エラストマーに扔ける 添加剤分析にも多用される。これらのポリマーはどんなに 上手に溶媒を選択しても低分子量成分が溶解し分析を妨害 するため, 添加剤が溶け込んでいる液とポリマーを完全に 分別するために用いられる.

\section{2 溶媒抽出法}

ソックスレー抽出器などの連続抽出器を用いる方法 （JISK6229）及び超音波照射を行い抽出する方法などがあ る.

溶媒抽出法は添加剂の種類, 抽出方法, 試料の表面積, 溶媒の種類と量, ソックスレー抽出装置の還流速度, 抽出 時間など様々な条件で抽出効率が異なるため, 配合既知の 試料を用いて抽出条件と抽出物の回収率を事前に確認して おく必要がある．特に抽出時の試料形態は抽出効率に大き く関与するため, ロールによる粉砕，フリーザーミルを用 いた冷凍粉砕による微粉末化，あるいは八サミなどで 2 $3 \mathrm{~mm}$ 角以下に細断するなど, 試駼項目と目的を考慮し可 能な限り溶媒との接触面積をより大きくして抽出効率をあ げるようにする。

例えばNBRの加硫ゴム製品の添加剤分析を行う場合は, 抽出効率をよくするため練りロールによる粉砕もしくは圧 延を行い, その後八サミで $2 \mathrm{~mm}$ 角の大きさに細断しソッ クスレー抽出を 16 時間行う。この際使用する溶媒はジエ チルエーテルである．仮にNBRのような極性ゴムに極性 溶媒であるアセトンを用いるとゴムの一部が溶解し，その 後の分析の妨害をすることもある. あらかじめゴム種の定 性を行い，極性ゴムには非極性溶媒を，非極性ゴムには極 性溶媒を用いるなど, 適正な抽出溶媒の選定が重要となる。 またNBRはロールによる粉砕を行うと内部発熱を起こし 手でつかめないほどの熱を発生する場合がある，可塑剤の 定量などには大きな影響はないが, 微量の遊離硫黄分析な どを行う際は冷却ロールを使うかハサミによる細断を行う かなどの配慮が必要となる。またシリコーンゴムや通常よ り無機充てん剤の割合が多い加硫ゴム製品の場合, 静電気 が発生しやすいためロールによる粉砕を行うとロールに密 着し剥がし取るのが困難になる.

一方過酸化物の残存物や揮発性物質の分析を目的とする 場合は, 分析段階での消失を避けるために通常密閉容器中 で保存し, サンプリングはハサミで細断後速やかに密閉容
器に入れるか溶媒中に浸せきし抽出を行う.

\section{3 超臨界流体抽出(Supercritical Fluid Extraction, SFE)法}

有機溶媒のかわりに超臨界状態の流体を用いてゴム製品 から添加剤を抽出する. 超臨界流体として最も一般的なも のは $\mathrm{CO}_{2}$ であるが, $\mathrm{CO}_{2}$ は無極性であるため極性化合物は 抽出されない．しかしゴムの添加剤は無極性物質に限られ てはいないため, 実際には $\mathrm{CO}_{2}$ の超臨界流体のほかに, メ タノールなどのモディファイヤーを添加し，極性の異なる 様々な物質の抽出を行う等の工夫が必要である.

実際に加硫ゴム製品の老化防止剤を SFE と従来のソッ クスレー抽出法で抽出しHPLCで定量した結果, 同等もし くはSFEの方が優れた結果が得られている ${ }^{4,5)}$.

このSFEは従来の溶媒抽出法に変わる方法としてだけ でなく, 各種のクロマトグラフィーと直結することで抽出 と分離および測定が同時に可能となり, 分析効率の向上が さらに図れる利点がある。これにはキャピラリーカラムを 用いて行うキャピラリーSFCと充てんカラムを用いて行 う充てんカラム $\mathrm{SFC}$ の 2 つ方法がある.

\section{4 加熱脱着法(熱抽出法)}

前項の $2.1,2.2,2.3$ が基材のゴム分と添加剤の分離を行 いその後分離した抽出物の分析を行うのに対し，この熱抽 出法はゴム製品を直接分析できる．前処理をせずに迅速か つ簡便に分析ができるのが特徴であるが，比較的高価な装 置を必要とするため分析コストを押し上げることになる。 詳細は加硫促進剤分析の項で述べる.

\section{3. スクリーニング分析}

添加剤は多種類のものが様々なオーダーで添加されてい る. 例えば可塑剤は数十\%添加されるのに対して老化防止 剤は $1 \%$ に満たない. よって, あらかじめスクリーニン グ的に分析を行い抽出物の主成分を㧍拈よそ把握すること により，その後に必要な前処理の選択ができ分析の精度を 向上させることができる.

\section{1 フーリエ変換赤外分光光度計(FT-IR)によるスク リーニング}

抽出物の主成分を分析する手法としてはFT-IRがもっ とも有効である. 可塑剤 (軟化剂)の場合は FT-IRで定性 が可能となる場合も多い. しかし逆に，軟化剤として鉱物 油が多量添加されている場合は, その他の少量の添加凨成 分の検出を妨害する場合がある. FT-IR 分析で抽出物に 多量の鉱物油が含まれている結果が得られた場合は，抽出 物をシリカゲルなどのカラムクロマトグラフィーを用いて 極性によって分画し分画物ごとに分析を行う。この操作を 行うことでより精度が向上する. 図 1 にEPDMのア七ト ン抽出物をシリカゲルカラムクロマトグラフィーで分離精 製処理前後の GC/MSクロマトグラムを示す．処理前では 

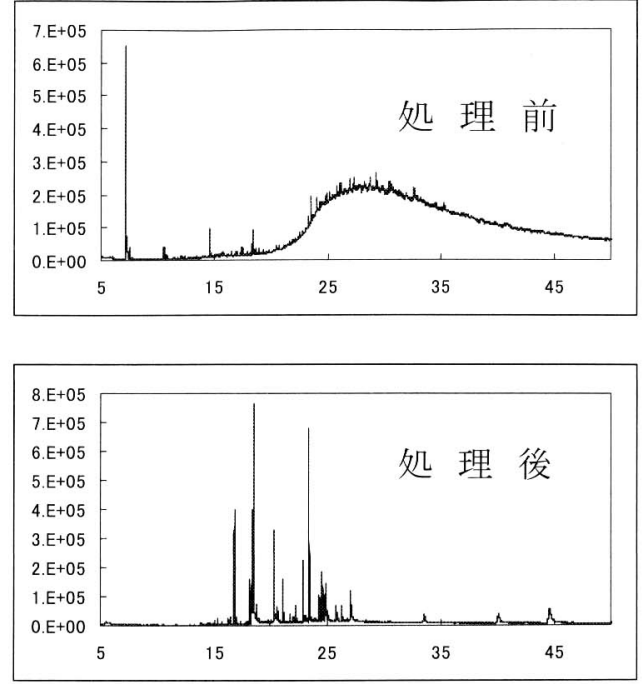

図 1 EPDMアセトン抽出物の GC/MSクロマトグラム

アセトフェノンと鉱物油のみしか検出されていないもの が，カラム処理後においては多数のピークが検出され, 脂 肪酸や老化防止郕などを検出することが可能となった.

\section{2 薄層クロマトグラフィー(TLC)によるスクリーニ ング}

TLC 法は分離能力及び定性 - 定量の精度の点で他の分 析手法に劣るが，簡便な手法であることから加硫促進剂及 び老化防止剂などの簡易分析法として大変有効である.ゴ ム製品から抽出した抽出物をジクロロメタンに溶解し，キ ヤピラリーでシリカゲルやアルミナなどのTLCプレート にスポットする，その後へキサンやメタノールなどの溶媒 を飽和させた展開槽のなかで展開させる．検出方法は 0.2 $\% の 2,6-$ - クロロロキンクロロイミドのエタノール溶液 などの発色試薬を使用するか, もしくはあらかじめ蛍光試 薬を担持させたプレートを用い紫外線を照射して行う．添 加剤の定性は同じ条件で測定した標準試料のスポットの $R_{f}$ 值と呈色とを比較して行う。加硫促進剤及び老化防止剤の 標品について分析した事例も数多く紹介されている ${ }^{6,7)}$. しかし $R_{f}$ 值は共存する他の添加剤の影響で変化すること もあるため，実際のゴム製品の抽出物の分析を行う際はお およその見当をつけた標準品と被検体試料を実際に同一条 件で分析を行うことでより精度があがる．そのためにも標 準となる多種の配合剤をそろえ，所定の条件で測定し $R_{f}$ 值の測定をするとともに，呈色後のTLCプレートを写真 に残し標準写真集を作成しておくと，未知試料の分析の際 にさらに有効となる.

実際に筆者らはシリカゲルのプレートに抽出物をスポッ トし， n一ヘキサン／酢酸エチル $(80 / 20)$ を展開液に用い, $0.2 \%$ \% 2 6-ジクロロキノンクロロイミドのエタノール溶 液で発色させ, 加硫促進剂や老化防止剂の定性分析を行っ ている。この TLC法は後項で紹介するような HPLC法や $\mathrm{GC} / \mathrm{MS}$ 法では分析が難解である金属塩，例えば加硫促進
剤のジチオカルバミン酸亜鉛などの分析が容易に行える点 でも優れている. またこの発色試薬で発色すると, 加硫促 進剤のジメチルジチオカルバミン酸亜鉛のようなジチオカ ルバミン酸亜鉛はだいだい色を呈し，CRに用いられるエ チレンチオウレアのようなチオウレア系は赤茶色を呈す る。一方老化防止剤の 6 -エトキシー 1,2 -ジヒドロ- $2,2,4$ トリメチルキノリンのようなキノリン系は青緑色を呈し，

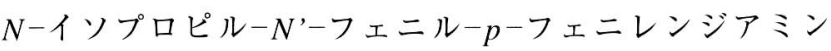
(IPPD)のようなアミン系は始め黄色だが時間が経過する と徐々に黒ずんでくる。このように構造の分類ごとに発色 具合が異なるため，発色した色を観察することで添加剤の 推察が容易になる.

また標準物質との照合で同定ができなかった場合は，ス ポット部をシリカゲルごとかき取りそれらを有機溶郕で再 抽出し, 得られた抽出液を $\mathrm{IR}, \mathrm{GC} / \mathrm{MS}, \mathrm{LC} / \mathrm{MS}$ 法など で分析を行う。このTLCで抽出液を分離しその後機器分 析にかけ定性を行う手法は，製品の污染物質や変色の要因 物質を特定する際にとても有用である。例えば，図 2 に示 すようなゴム製品（上層から白色 EPDM /黑色 EPDM 黑色 $\mathrm{CR}$ )の上層の白色 $\mathrm{EPDM}$ が褐色に変色し, この変色 要因を調査した事例がある。この場合まず各層ごとにソッ クスレー抽出すると, 褐色に变色していたEPDMは脱色 し初期の白色に戻った．抽出物は褐色を呈していたため, 変色の要因となった物質は完全に抽出されたとものと考え られる。この際比較のため各層の未使用品についても同様 の操作を行った。得られた抽出物をTLCで分析した結果， 四 3 に示すように未使用品の白色 EPDM と黒色EPDMに は褐色のスポットは認められず，一方未使用品黒色 CR 変色品の白色 EPDM，黑色EPDM，黒色 CRから同位置に

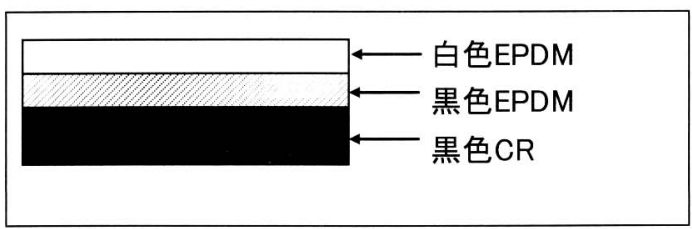

図 2 白色EPDMが変色したゴム製品構造

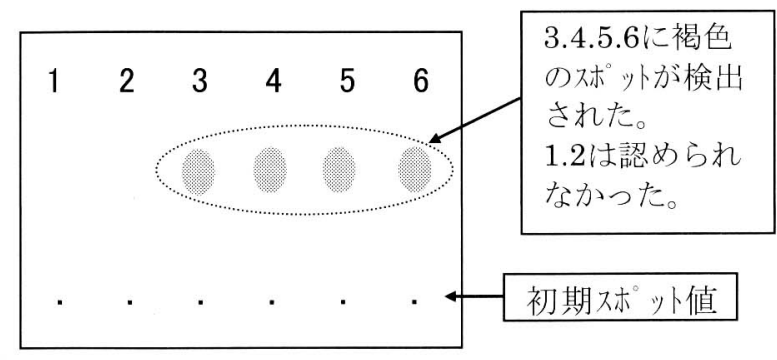

\begin{tabular}{|l|l|}
\hline 1. 白色EPDM (未使用品) & 4. 白色EPDM \\
\hline 2. 黒色EPDM (未使用品) & 5. 黒色EPDM \\
\hline 3. 黒色CR(未使用品) & 6. 黒色CR \\
\hline
\end{tabular}

図 3 TLC 分析の結果 
褐色のスポットが検出された。これらの結果より褐色の変 色要因は黒色 CRに添加されていた配合郕が, 黒色 CRか ら黒色EPDMを経て白色 EPDMに移行し変色を及ぼした ということが明らかとなった.

次にこのスポットを掻き取りジクロロメタンを用いて抽 出し抽出物を $\mathrm{GC} / \mathrm{MS}$ で分析した結果, IPPDが検出され た. よってこの白色 EPDMの変色は黒色 CRに配合された 老化防止羭のIPPDが原因であったことが判明した.

\section{4. 配合剤の分析}

\section{1 加硫剤の分析}

ゴムは加硫反応を生じさせることで，ゴムの分子間に三 次元の網目構造が生じ, 強度や耐久性などの諸物性が向上 する.

加硫剤には硫黄, 金属酸化物, チウラム系物質, 過酸化 物，キノンジオキシム，アルキルフェノール樹脂，アミン 化合物などがある，NR，SBR，NBRなどのジエン系ゴム には硫黄やチウラム系化合物が多く用いられる。硫黄の分 析についてはゴムを酸素燃焼フラスコで完全に燃焼し硫酸 イオンとして定量するなどの方法がある(JIS K6233)。通 常, 硫黄は加硫工程で配合された量のすべてが反応に関与 するのではなく，一部はそのままゴム中に残る。これを遊 離硫黄といい有効な加硫形成がなされているか否かの判定 材料になる.「JIS K6234 ゴム-遊離硫黄の定量」に亜硫酸 ナトリウム法, 臭素法, 銅網法 A 法, B法の 4 方法が記述 されている.一方チウラム系化合物は，図 4 に示すように 加硫反応後は加硫促進助剂の $\mathrm{ZnO}$ と反応してカルバミン 酸西鉛の構造になるため, チウラム系化合物のまま抽出し 特定することは困難である.

過酸化物はEPMやシリコーンゴムに多用される．加硫 後ゴム中に過酸化物の分解物が残存している場合は，パー ジ\&トラップーガスクロマトグラフ／質量分析計 $(\mathrm{P} \& \mathrm{~T}-$ GC/MS)もしくは溶媒に浸せき抽出し抽出液を $\mathrm{GC} / \mathrm{MS}$ 分 析することで，使用された過酸化物の同定が可能となる. 例えば過酸化物架橋で多く使用されているジクミルパーオ キシド (DCP) は分解物としてクミルアルコールやアセ卜 フェノンが検出される．DCPによる架橋PE製品が使用中 に亀裂が発生したようなトラブル事例があるが，この一要 因として残存した過酸化物が成形品中で少しずつラジカル を発生し製品の劣化を誘引促進することがあげられる。よ
ってクミルアルコールやアセトフェノンの定量を行うこと でトラブル解決への手懸りをつかむことが可能となる.

金属酸化物の亜鉛華 $(\mathrm{ZnO})$ 及び酸化マグネシウムは $\mathrm{CR}$, クロロスルホン化ポリエチレン (CSM) などに用いられる が，これらはX線回折で同定が可能である. その他キノン ジオキシムやアミン化合物は加硫時にわずかに残存してい る場合，抽出物を GC/MSで分析し検出することがまれに できるが，多くの場合加硫剤はゴム中でゴム分子鎖と反応 し結合するため, 加硫剂としての分析は困難である場合が 多い.

\section{2 加硫促進阂の分析}

ゴムと加硫剤との加硫反応を促進させ, 加硫時間の短縮, 加硫温度の低下, 加硫剤の減量などのために添加されるの が加硫促進剂である. 加硫促進剂はチアゾール系，スルフ エンアミド系, チウラム系, ジチオカルバミン酸塩 (ジチ オカルバメート)系, グアニジン系, チオウレア系, キサ ンドゲン酸塩系, アルデヒドアミン系, アルデヒドアンモ ニア系などに分類される。これらの加硫促進剂の簡易分析 手法として 3.2 項で紹介した抽出物のTLC分析があげられ る.しかしソックスレー抽出法及び加熱還流法は抽出時に 加熱が必要であるため, 加硫促進剤が熱変化を起こしてし まう可能性がある.よって可能な限り低沸点の溶媒を用い るか, 室温下で振とう抽出する方法などの検討が必要であ るが，振とう抽出の場合，抽出効率にやや問題もある．抽 出物を分析する段階で熱による変化がないのはTLC 法, HPLC 法である. しかし未知試料の場合の同定の精度を考 慮すると， GC/MS 法やP \& T-GC/MS 法や PyGC/MS 法 はよりベターな分析手法として推薦できる.

また加硫促進剤は加硫反応の途上でその大部分が分解す るか別の化合物に変化する.未反応の加硫促進剂がゴム中 に残存している場合は配合された加硫促進剤を同定できる が，通常ではすでに加硫反応の終了した加硫促進肪を同定 しさらに定量することは不可能である．例えばチアゾール 系の 2 -メルカプトベンゾチアゾール $(\mathrm{MBT})$, ジベンゾチ アジルジスルフィド (MBTS) , 2-メルカプトベンゾチア ゾールの亜鉛塩 $(Z n M B T)$ のいずれを使用しても，加硫反 応時に $\mathrm{ZnO}$ と反応してすべて $\mathrm{ZnMBT}$ に変化してしまう。 よって分析の結果からZnMBTが検出されたとしても, 加 硫促進剤としてMBT, MBTS, ZnMBTの 3 者のいずれ が配合されたのかを同定することはできない.またチウラ

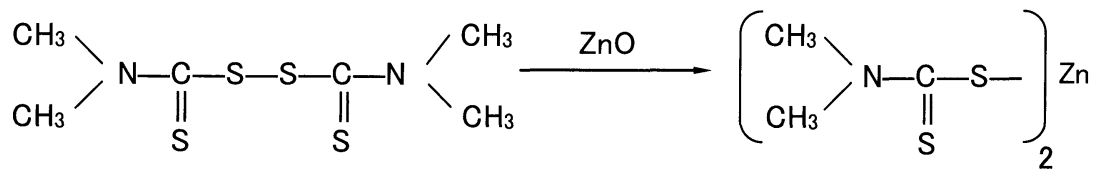

TMTD

ZnMDC

図 4 TMTDの最終的な反応生成物 
表 1 加硫促進剛の種類と加硫反応後の生成物

\begin{tabular}{l|l}
\hline \multicolumn{1}{c|}{ 種類 } & \multicolumn{1}{c}{ 加硫反応後の生成物 } \\
\hline チアゾール系 & $\begin{array}{l}\text { チアゾール類 } \\
\text { メルカプドンゾチアゾールの亜鉛塩 }\end{array}$ \\
\hline スルフェンアミド系 & チアゾール類, アミン \\
\hline チウラム系 & ジチオカルバミン酸亜鉛塩 \\
\hline ジチオカルバミン酸塩系 & 変化なし \\
\hline グアニジン系 & 変化なし \\
\hline チオウレア系 & チオウレア, ウレア \\
\hline キサンドゲン酸塩系 & 変化なし \\
\hline アルデヒドアミン系 & 不明 \\
\hline
\end{tabular}

ム系の場合は $\mathrm{ZnO}$ と反応してジチオカルバミン酸塩が生 成し，チウラム系物質がそのままの構造で検出されること はほとんど不可能に近い. 表 1 に加硫促進剤の加硫反応に よる変化を示す．加硫促進剤の同定を行う際は，分析して 得られた結果と，配合についての知識及び加硫ゴムの諸物 性データや用途などを考慮して推定することが必要とな る.

4.2 .1 高速液体クロマトグラフ（HPLC）先に述べた ように加硫促進剤は熱安定性が悪いため，分析段階で熱変 化を生じないHPLC 法やTLC 法は加硫促進剂の分析には 大変有効であり，分離能力及び定性・定量性から TLC 法 より HPLC法が格段に優れているといえるだろう。この HPLC 法については「JISK6220-2 ゴム用配合剂一試験方 法一第二部：有機加硫促進剂及び有機加硫剤」にも記され ているが，基本的にはODSカラムを用い，精製水／メ夕 ノールや精製水／アクリロニトリルを溶離液として，紫外 可視検出器やフォドダイオードアレイ検出器で分析が可能
である。

また加硫促進剤はアミン系老化防止剂も含めてアレルギ 一性接触皮膚炎の要因の一つでもあり，数多くアレルギー 性のパッチテストや加硫促進剤の分析手法が調査されてい $3^{8,9)}$. また日本ゴム協会 分析研究分科会が加硫促進剤 の分析方法について文献調查した結果を「加硫促進剂分析 法 文献抄録集」としてまとめているのでぜひ参考にされ たい。ささらに「JIS T9010ゴム製品の生物学的安全性に 関する試験方法」にも記述されている.

4.2.2 P \& T-GC/MS 物質の分離能力, 定性能力さ らには迅速性では GC/MSはもっとも優れた分析手法とい える，GC/MS 法にはゴムから抽出した抽出物をインジェ クションを用いて直接 GCに導入し GC/MSで分析する方 法, 前処理操作をせずにゴム製品をそのまま分析装置に導 入し分析する P \& T-GC/MS 法, 熱分解 GC/MS 法などが ある。

この P\&T-GC/MSはゴムの定性分析で多用されている キューリーポイント加熱法 (PyGC 法)をパージ\&トラップ 方式のヘッドスペースサンプラー (P\&T)に利用した装置 であり，特徴はゴム製品数 $\mathrm{mg}$ を前処理操作無くそのまま 分析機器に導入することで分析することができ, 試料量が 少量で分析に要する時間が極めて短い。これらの分析でゴ 厶製品中の揮発性物質の分析が可能となり，加硫促進剂の MBTSでは分解物のベンゾチアゾールを，CBSではベン ゾチアゾールとシクロヘキサアミンを，BBSではベンゾ チアゾールと $\mathrm{t}$ チブチルアミンが検出される(図 5 )。よっ て，これらの分解物から添加されていた加硫促進剂の推定

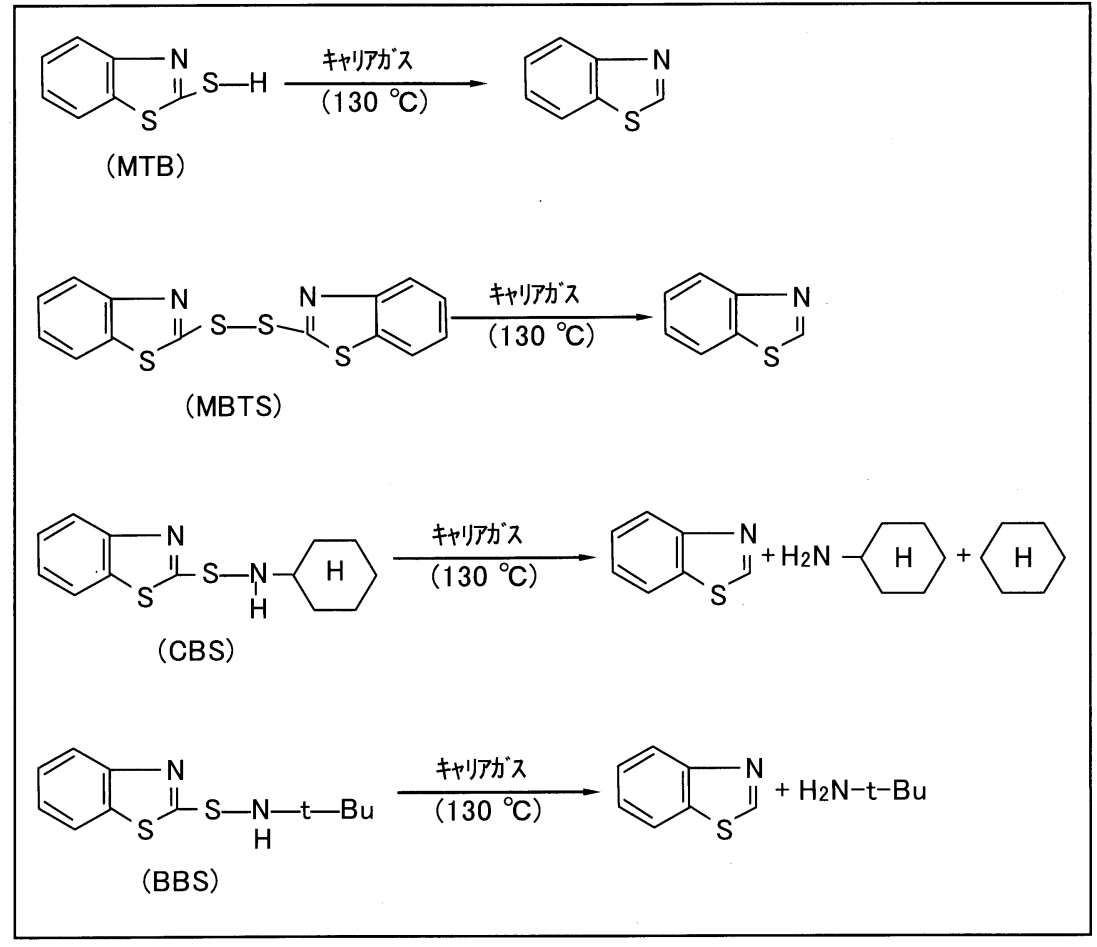

図 $5 \mathrm{P} \& \mathrm{~T}-\mathrm{GC} / \mathrm{MS}$ 法による加硫促進剂の分析結果 
が可能となる ${ }^{10)}$.

この手法は加硫促進剤だけではなく, 老化防止剂の分析 やゴム製品にある一定温度をかけた場合に発生する加熱発 生ガスの分析にも有効である．例えばあるゴム製品を 150 ${ }^{\circ} \mathrm{C}, 200{ }^{\circ} \mathrm{C}, 300{ }^{\circ} \mathrm{C}$ 条件下で使用した際, どのような物質 が生じ，温度と時間に対してどのような依存性を示すかな どを調査する際，大変優れた手法となる.

\section{3 老化防止剤の分析}

ゴム製品は使用中の熱, 酸素, オゾン, 光, 重金属 (銅, マンガンなど), 動的㾉労など数多くの劣化因子によって 物性の低下 (硬化, 軟化, 弾性損失など) や亀裂を発生し, 製品としての機能を保持することができなくなる．これら を防ぎ製品としての寿命延長のために用いられるのが老化 防止剂である. 老化防止剤には大別してアミン系, フェノ 一ル系, りん酸系, キノリン系, ベンゾイミダゾール系, ジチオカルバミン酸系, 有機チオ酸系, ワックス系などが あるが加硫ゴム, プラスチック, 熱可塑性エラストマーを 問わず添加剤の分析としてはもっとも重要で, なおかつ関 心のある分析項目である. 事実我々の機構に依頼のある添 加剤の分析の中でもっとも依頼数が多い。

分析手法としてはゴム製品から溶媒抽出し抽出物を TLC, FT-IR, GC, GC/MS, GC/AED, HPLC, $\mathrm{LC} / \mathrm{MS}$ な゙で分析をする。この項では $\mathrm{GC} / \mathrm{MS}$, GC/AED と LC/MSを紹介する. また日本ゴム協会 分析 研究分科会では老化防止剂の分析方法についても文献調査 した結果を「老化防止剤分析法 文献抄録集」としてまと めているのでぜひ参考にされたい.

\section{3 .1 ガスクロマトグラフ/質量分析計(GC/MS) キ} ヤピラリーカラムを用いた GC/MS 分析は分解能及び作業 性からもっとも多用されている手法のひとつといえる. 使 用するカラムの選択により検出される物質に限界はある が，微極性カラムを用いれば老化防止剤の多くは検出され る. 近年キャピラリーカラムの高分解能と, 検出器である MSの高選択性から微量分析が可能になり，3.2項で述べた ような変色の要因物質の特定を行う際は大変有効な手法で ある. 市販のマススペクトルデータベース (Nist, Wiley など）もかなり充実している，例えば図 1 に示したEPDM のアセトン抽出物をライブラリーを用いて詳細に解析する と, DCPの分解物であるアセトフェノン, 滑剤のパルミ チン酸やステアリン酸, 可塑剤のトリクレジルホスフェー ト $(\mathrm{TCP})$ 及びフェノール系酸化防止剂の $n$-オクタデシル3-(4'-ヒドロキシ-3', 5'-ジーtーブチルフェニル)プロピオ ネートなどが一回の分析で同定できた。しかしゴムの添加 剂はまだまだ特殊分野であるため, 老化防止剂としてNR や他の合成ゴム各種に用いられる 2,2 -メチレンービス- $(6$ - $\alpha$-メチルーベンジルー4-メチルフェノール)などはデー夕 ベースに登録されていない.よって独自にプライベートラ
イブラリーを作成し，市販ライブラリーと併用することで 分析精度は格段に向上する。

GC/MSのイオン化法としてはEI(電子衝撃イオン化)法 が一般的だが, 未知試料の場合はCI (化学イオン化) 法に よって分子量の推定も行うことができる.

\section{3 .2 ガスクロマトグラフ/原子発光検出器 (GC/} AED) 原子発光検出器 (AED) の特徵は他の GC/FID や $\mathrm{GC} / \mathrm{MS}$ と異なり, $\mathrm{N}, \mathrm{S}, \mathrm{Cl}, \mathrm{P}$ というような元素ごとに モニターできることである. 例えば多種の添加剤が混在し ている抽出物を $\mathrm{GC} / \mathrm{MS}$ 分析すると多数のピークが検出さ れる.この抽出物を $\mathrm{GC} / \mathrm{AED}$ 分析し, $\mathrm{C}, \mathrm{H}, \mathrm{O}, \mathrm{N}, \mathrm{Cl}$ などをモニターすると, それらの検出されたピークの物質 が酸素含有化合物であるか, 窒素含有化合物 (例：アミン 系物質)であるか, 塩素含有化合物であるかの判別ができ る11).アレルギー性接触皮虑炎などの問題からゴム製品中 の窒素を含有する添加剤の有無, 有害性の問題から塩素系 や臭素系の添加剂の有無などの観点で分析を行うときな ど, 元素の選択性のある $\mathrm{GC} / \mathrm{AED}$ は極めて有効となる.

\section{3 .3 液体クロマトグラフ/質量分析計 (LC/MS)} GC/MS で検出されないような難揮発性の添加剤の分析や 熱に不安定な物質にはLC/MSが有効となる．近年の添加 剤は高分子量化する傾向にあり GC/MSでは検出されにく いが，LC/MS 分析はこれら高分子量添加剤に対して有効 である.LC/MSのイオン化法としてはESI(エレクトロス プレーイオン化) と APCI(大気圧イオン化)があるが，こ のイオン化法で大きく検出感度が変わるため, 被検体物質 に適したイオン化法の選択が重要となる．未知試料の場合 まずトライアル的にESI法を薦める。また，LC/MSでは フラグメンテーションがほとんど起きないため分子量の情 報のみが得られるが, タンデム型 (LC/MS/MS)の検出器 を用いることで, MS 1 で選択したイオンをさらにイオン 化しフラグメンテーションを起こさせ，分子量以外の側鎖 基などの情報が得られ構造解析が可能となる。しかし GC/MSのよjには市販ライブラリーが充実していないた め, 詳細な解析を行うためには基礎デー夕などの収集がど うしても必要となる。

\section{4 難燃剤の分析}

有機材料であるゴム製品は燃えやすい性質がある．これ を改良するために添加されるのが難燃剤である．難燃剤に は三酸化アンチモンや水酸化アルミニウムなどの無機難燃 片と, 臭素系, 塩素系, リン系, 含窒素化合物, シリコー ン系などの有機難燃剤がある。無機難燃剤はゴム製品のま まX線回折で分析し容易に同定が可能である。一方有機 難燃剂はゴム製品から抽出し抽出物の分析を行い同定す る.

近年グリーン調達が積極的に推進され，2003年には E $\mathrm{U}$ 加盟国で「電気・電子機器に含まれる特定有害物質の使 
用制限指令」(RoHS 指令 $(2002 / 95 / E C))$ が発効し， 2006 年 7 月 1 日より日本及び欧州などの各地域で製品含有化学 物質の法規制が強化される。この RoHS指令には臭素系難 燃剤であるポリ臭化ビフェニル $(\mathrm{PBB})$ 及びポリ臭化ジフェ ニルエーテル $(\mathrm{PBDE})$ が含まれており，今後ゴム中の PBB,PBDEの分析の必要性が高まると考えられる。本項 はPBB，PBDEの分析を中心に紹介するが，他の有機難 燃剂についてもこれらの手法が応用できる.

4.4 .1 GC/MSによる分析 2.2 項に紹介した溶媒抽出 法で抽出溶媒としてトルエン, クロロホルム, ジクロロメ タンなどを用いて難燃殽を抽出する。 得られた抽出物に共 雑物が多い場合はシリカゲルカラムクロマトグラフィーで クリーンアップ(抽出物の精製)を行う。 その後 GC/MSで 分析を行うが，これらの $\mathrm{PBB}, \mathrm{PBDE}$ の分子量は約 1000 のものもあるため, 膜厚が薄く高温使用のカラムを用いる. 表 2 に分析条件の一例を示す. 近年は使用温度上限が 400 ${ }^{\circ} \mathrm{C}$ のキャピラリーカラムも開発され, 分離もよくさらに分 析時間の短縮が図られている。しかしこれらの物質は異性 体が多く存在するため, 同定し定量する際は $\mathrm{GC} / \mathrm{MS}$ 分析 の十分な経験が必要となる.

4.4 .2 蛍光X線によるスクリーニング分析 近年エネ ルギー分散型蛍光 $\mathrm{X}$ 線装置 (EDX) の感度が向上し, 特に RoHS 関連ではエネルギー分散型蛍光X線装置によるスク リーニング分析が有効である．EDXはゴム製品のままの 非破壊分析で数分の測定時間で分析が可能である. 検出感 度は共存するマトリックス層の影響をうけるが，数十 ppm オーダーの含有量まで検出することが可能である. しかしEDXの場合臭素元素として検出されるため, 臭素 が検出された場合それがPBBまたはPBDE由来であるの か，それともその他の臭素系難燃剤であるかの判別ができ ない.よってEDX分析で臭素が検出された場合，4.4.1の

\section{表 $2 \mathrm{PBB}, \mathrm{PBDE}$ の GC/MS 分析条件}

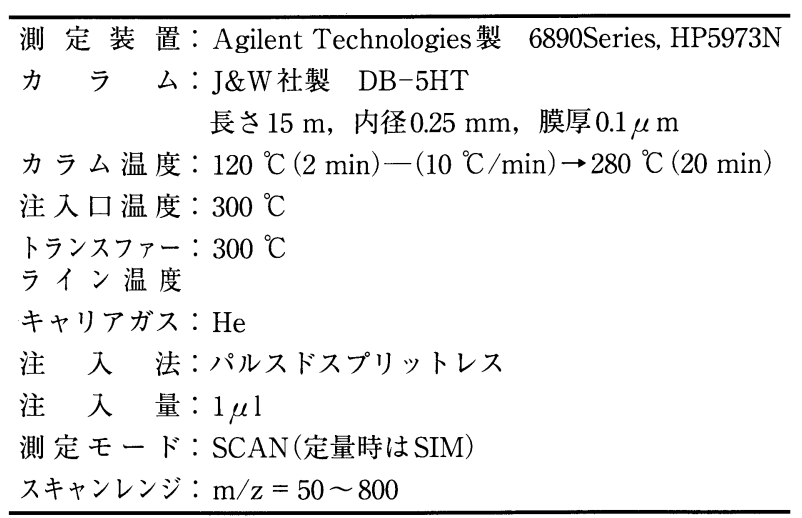

GC/MSで詳細な定性・定量分析を行う必要がある.

4.4 .3 高温燃焼ーイオンクロマトグラフ 試料を管状 電気炉などで約 $800{ }^{\circ} \mathrm{C}$ 高温で完全に燃焼させ, 生成した 臭素を $0.1 \mathrm{~N}$ 水酸化ナトリウム溶液に吸収させ, 吸収液中 の臭素イオンをイオンクロマトグラフィーなどで定量す る.この手法では総臭素量を定量することになる.

\section{5. おわりに}

以上, ゴムに添加された加硫(架橋)系薬剤, 老化防止剤, 及び難燃剤についての分析手法を紹介した．添加剤は日々 開発されている. それに伴い分析手法も製品開発同様の弛 まぬ開発と工夫が必要とされる。本稿が少しでも現場技術 者の日ごろの分析業務や添加剤に対する考え方などのお役 に立てれば幸甚である。

\section{References}

1 ) Ohtake, Y., Furukawa,M.: "Zairyou Trouble Tyousa File", Nikkan Kougyou Shinbun, Tokyo (1999)

2 ) Ohtake, Y.: "Koubunshi Zairyou no Jikogenin Kyumei to PL Hou", Agune Gizyutsu Center, Tokyo (1999)

3) Ohtake, Y.: "Gomu-Plastic Zairyou no Trouble to Taisaku", Nikkan Kougyou Shinbun,Tokyo (2005)

4 ) Werthmann, B., Neyen, V., Milczewski, F., Borowski, R.: Kautsch. Gummi Kunstst., 51, 118 (1998)

5 ) Werthmann, B., Neyen, V., Borowski, R. Kretzschmar, H. J.: Kautsch. Gummi Kunstst., 48, 494 (1995)

6) Nishiguchi, K.: Chibaken Kougyou Shikenzyo Kenkyuu Houkoku, No.9, 3 (1995)

7 ) Watanabe, T.: Gomu Gizyutsu Symposium Text, Nippon Gomu Kyokai, 41, 73 (1995)

8 ) Kaniwa, M., Isama, K., Nakamura, A., Kanetoh, H., Hosono, K., Itoh, M., Shibata, K., Usuda, T., Asahi, K., Osada, T., Matsunaga, K., Ueda, H.: Contact Deratitis, 31, 65 (1994)

9 ) Kaniwa, M.: Hifu 35(16), 21 (1993)

10) Ohkuri, N.: Nippon Gomu Kyokaishi, 67, 768 (1994)

11) David, F., Sandra, P.: Liq Chromatogr Gas Chromatogr, 11, 282 (1993)

\section{日本語表記参考文献}

1) 大武義人, 古川睦久：“材料トラブル調査ファイル”, 日刊工業 新聞社, 東京 (1999)

2 ) 大武義人： “高分子材料の事故原因究明と PL法”，アグネ技術セ ンター, 東京 (1999)

3 ）大武義人：“ゴム・プラスチック材料のトラブルと対策”, 日刊 工業新聞社, 東京 (2005)

6 ）西口勝久: 千葉県工業試験所研究報告, No. 9, 3 (1995)

7 ）渡辺綱治：ゴム技術シンポジウムテキスト，日本ゴム協会， 41, 73 (1995)

9 ）鹿庭正昭：皮虞, 35(増 16), 21 (1993)

10）大栗直毅：日本ゴム協会誌，67，768 (1994) 